\title{
UPAYA MAKSIMALISASI KOMPETENSI PAEDAGOGIS GURU BERBASIS KETERAMPILAN DASAR MENGAJAR DI MTS AL-IKHLASIYAH PERAMPUAN LABUAPI LOMBOK BARAT
}

\author{
Abdul Fattah \\ Institut Agama Islam Negeri Mataram \\ E-mail: fath_smart@yahoo.com
}

\begin{abstract}
Abstrak: Dalam rangka maksimalisasi kompetensi paedagogis guru berbasis keterampilan dasar mengajar di MTs Al-Ikhlasiyah Perampuan, Labuapi, Lombok Barat. Madrasah ini telah berdiri sejak 27 tahun lalu, namun masih banyak menghadapi hambatan, terutama berkaitan dengan masalah kualifikasi dan kompetensi guru. Kompetensi guru MTs Al-Ikhlasiyah Perampuan telah dilakukan pembinaan dan pengembangan secara fungsional, sehingga memiliki kompetensi yang tinggi, terutama dalam hal kompetensi paedagogis dasar bagi seorang guru, yang meliputi komptensi membuka dan menutup pelajaran, keterampilan bertanya, keterampilan menjelaskan, dan sebagainya. Dalam kegiatan pembekalan-pelatihan ini dimaksudkan untuk memberikan orientasi dengan tujuan memberikan wawasan dan pengetahuan bagi segenap guru MTs Al-Ikhlasiyah yang menjadi peserta sebanyak 15 orang tentang konsep-konsep upaya peningkatan kompetensi paedagogis guru berbasis keterampilan dasar mengajar yang mutakhir. Kegiatan ini dalam penerapannya menggunakan metode ceramah, diskusi maupun latihan tugas tentang berbagai penting terkait kompetensi paedagogis guru. Termasuk dalam hal ini adalah konsep hypnoteaching dalam pembelajaran sebagai bagian dari metode menjelaskan. Sedangkan pendampingan merupakan kegiatan sebagai follow up dari kegiatan pembekalan-pelatihan agar guru yang berjumlah 15 orang selaku peserta tersebut benar-benar memiliki skill terbaru yang terkait dengan kepentingan implementasi kompetensi paedagogis guru berbasis keterampilan dasar mengajar. Kegiatan pemberdayaan Kompetensi Paedagogis Guru Berbasis Keterampilan Dasar Mengajar dan Metode Hypnoteaching di Madrasah Tsanawiyah Al-Ikhlasiyah Desa Perampuan, Kabupaten Lombok Barat ini telah berjalan dengan lancar.
\end{abstract}

Kata Kunci: Kompetensi Paedagogis, Keterampilan Dasar Mengajar, Keterampilan Membuka, Keterampilan Menjelaskan, Keterampilan Menutup, Hypnoteaching

\section{PENDAHULUAN}

Memasuki era globalisasi, abad informasi, dan teknologi, yang terbayang dalam pikiran bersama adalah aspek kesiapan bangsa Indonesia pada era tersebut. Terlebih pada tahun 2015, memasuki fase "Masyarakat Ekonomi ASEAN (MEA)", bangsa ini tertantang untuk dapat menapakinya secara mulus, benar, dan dalam kerangka kerja yang fairplay. Namun, kegamangan demikian pantas muncul di permukaan, karena dilihat dari sisi sumber daya manusia Indonesia, seperti dalam penilaian Suyanto dan Abbs, bangsa ini masih pantas untuk disebut 
memprihatinkan. ${ }^{6}$ Lebih lanjut, dapat diungkap bahwa kini dunia pendidikan Indonesia mengalami kesuraman bahkan bisa disebut semakin carut-marut. ${ }^{7}$ Atas dasar itu, Tilaar menulis sebagai berikut:

Era abad 21 adalah era ilmu pengetahuan dan teknologi. Tanpa support ilmu pengetahuan dan teknologi, suatu masyarakat akan tertinggal dari perubahan. Oleh sebab itu, negara-negara baik negara maju maupun negara berkembang, memberikan perhatian yang tinggi terhadap pendidikan, khususnya pendidikan sains dan pengembangan teknologi. ${ }^{8}$

Banyak pihak menyadari bahwa pendidikan mempunyai peranan yang sangat strategis dalam pembangunan bangsa. Berbagai kajian di banyak negara menunjukkan kuatnya hubungan antara pendidikan dengan tingkat perkembangan bangsa-bangsa tersebut yang ditunjukkan oleh berbagai indikator ekonomi dan sosial budaya. Pendidikan yang mampu memfasilitasi perubahan adalah pendidikan yang merata, bermutu, dan relevan dengan kebutuhan masyarakat. Sehingga tidak berlebihan jika dikemukakan bahwa peningkatan mutu pendidikan, tampaknya masih merupakan isu sentral beberapa tahun ke depan atau mungkin untuk selamanya. ${ }^{9}$ Agar pembangunan pendidikan dapat berkontribusi terhadap peningkatan kualitas sumber daya manusia (SDM), terdapat tiga syarat utama yang harus diperhatikan yaitu: sarana gedung, buku yang memadai dan berkualitas, serta guru dan tenaga kependidikan yang profesional. ${ }^{10}$

Undang-Undang Republik Indonesia No. 20 tahun 2003 tentang Sistem Pendidikan Nasional mengemukakan bahwa pendidikan nasional bertujuan mengembangkan potensi peserta didik agar menjadi manusia yang beriman dan bertaqwa terhadap Tuhan Yang Maha Esa, berakhlak mulia, sehat, berilmu, cakap, kreatif, mandiri, dan menjadi warga negara yang demokratis serta

\footnotetext{
${ }^{6}$ Suyanto dan M.S. Abbas, Wajah dan Dinamika Pendidikan Anak Bangsa (Yogyakarta: Adicita Karya Nusa, 2004), h. 25.

${ }^{7}$ Nurrahmah, Potret Buram Pendidikan Daerah Miskin di Indonesia: Becermin dari Dompu Nusa Tenggara Barat (Mataram: Insan Madani Institute Mataram, 2014), h. 1.

${ }^{8}$ H.A.R. Tilaar, Perubahan Sosial dan Pendidikan: Pengantar Pedagogik Transformatif untuk Indonesia (Jakarta: PT Grasindo, 2002), h. 51.

${ }^{9}$ Robinson Situmorang, "Strategi Pembelajaran Berbasis Multiple Intelligence (MI) untuk Pencapaian Kompetensi dalam Pembelajaran", dalam Mozaik Teknologi Pendidikan, eds. Dewi Salma Prawiradilaga dan Eveline Siregar (Jakarta: Kencana, 2008), h. 59.

${ }^{10}$ E. Mulyasa, Menjadi Guru Profesional (Bandung: Remaja Rosdakarya, 2005), h. 3.
} 
bertanggungjawab dalam rangka mencerdaskan kehidupan bangsa. ${ }^{11}$ Untuk mencapai tujuan tersebut pemerintah telah menetapkan tiga rencana strategis yaitu: pertama, perluasan dan peningkatan akses; kedua, peningkatan mutu, relevansi dan daya saing; ketiga peningkatan tata kelola pendidikan, transparansi dan akuntabilitas pelaksanaan pendidikan.

Mengingat peran guru yang begitu besar dalam proses pembelajaran, maka diperlukan guru yang profesional, kreatif, inovatif, mempunyai kemauan yang tinggi untuk terus belajar, melek terhadap teknologi informasi, sehingga mampu mengikuti perkembangan zaman. Tuntutan profesionalisme guru terus didengungkan oleh berbagai kalangan di masyarakat kita, termasuk kalangan guru sendiri melalui berbagai organisasi guru yang ada, di samping tuntutan perbaikan taraf hidup guru. Mereka berharap, untuk meningkatkan mutu dan kualitas pendidikan di Indonesia, diperlukan seorang guru yang profesional dalam mendidik siswa-siswinya di sekolah. Sejalan dengan tuntutan profesionalisme guru itulah, maka pemerintah mengeluarkan Undang-Undang Nomor 14 tahun 2005 tentang Guru dan Dosen. Dengan dikeluarkannya Undang-Undang tersebut guru diposisikan sebagai suatu profesi sebagaimana profesi dokter, hakim, jaksa, akuntan, dan profesi-profesi lain yang akan mendapat penghargaan sepadan sesuai dengan profesinya masing-masing.

Faktor tenaga kependidikan, khususnya di Pendidikan Dasar masih banyak yang belum memiliki ijazah Stara Satu (S1). Oleh karena itu, Kementerian Agama RI memiliki upaya membantu para guru melalui program beasiswa bagi yang memenuhi persyaratan agar dapat mengikuti perkuliahan di tempat yang ditentukan oleh Kementerian Agama. Guru di lingkungan Kementerian Agama yang bertugas di MI, MTs, MA berjumlah 524.543 orang. Dari jumlah tersebut guru MI dan PAI menempati peringkat pertama dari segi kuantitas. Fenomena di atas terjadi juga pada institusi Pendidikan di Provinsi NTB semisal sekolah/madrasah.

Sketsa buram kehidupan institusi sekolah/madrasah yang dieksplanasikan di atas, sesungguhnya juga terjadi di MTs Al-Ikhlasiyah Desa Perampuan, Kecamatan Lapuapi, Kabupaten Lombok Barat. Berdasarkan survey awal,

${ }^{11}$ Farida Sarimaya, Sertifikasi Guru Apa, Mengapa dan Bagaimana? (Bandung: CV.Yrama Widya, 2008), h. 112. 
terutama pada saat menjadi pembimbing mahasiswa PPL-2 Fakultas Ilmu Tarbiyah dan Keguruan IAIN Mataram, ditemukan bahwa keadaan manajemen madrasah masih banyak yang harus dibenahi. Hal yang ditekankan di sini juga adalah kompetensi paedagogis guru yang masih terdapat sedang menempuah pendidikan S1. Sedangkan yang lainnya guru yang mengajar bukan dari pendidikan S1 keguruan. ${ }^{12}$

Melalui kegiatan dokumentasi, observasi, dan wawancara dengan kepala madrasah Bpk. Sayadi, SE, terungkap bahwa MTs Al-Ikhlasiyah Perampuan merupakan MTs swasta, dan berdiri pada tahun 1989 dengan SK Pendirian no: WX/89.222 TS/3/1989. Madrasah ini memiliki tenaga pendidik atau guru yang diangkat oleh yayasan sebanyak 28 orang guru, dan tidak memiliki guru PNS. Latar belakang pendidikan guru sangat beragam, dengan kualifikasi akademik: 13 orang S1, 7 orang D2, dan 8 orang SMA/MA. Dari semua itu, yang berlatar belakang ilmu kependidikan berjumlah 8 orang dan non kependidikan sebanyak 5 orang. ${ }^{13}$

Tabel 1: Jumlah Tenaga Pengajar di MTs Al-Ikhlasiyah Perampuan Berdasarkan Latar Belakang Pendidikan

\begin{tabular}{|c|c|c|c|c|c|}
\hline \multirow[b]{2}{*}{ No } & \multicolumn{4}{|c|}{ LATAR BELAKANG PENDIDIKAN } & \multirow[b]{2}{*}{ KET } \\
\hline & S1 Kependidikan & $\begin{array}{c}\text { S1 } \\
\text { Non } \\
\text { Kependidikan }\end{array}$ & D2 & SMA & \\
\hline 1 & 8 & 5 & 7 & 8 & Non-PNS \\
\hline \multicolumn{4}{|c|}{ Total } & 28 & Non-PNS \\
\hline
\end{tabular}

MTs Al-Ikhlasiyah Perampuan yang meski telah berdiri sejak 27 tahun lalu, namun masih banyak menghadapi hambatan, terutama berkaitan dengan masalah kualifikasi dan kompetensi guru. Kompetensi guru MTs Al-Ikhlasiyah Perampuan perlu dilakukan pembinaan dan pengembangan secara fungsional, sehingga memiliki kompetensi yang tinggi, terutama dalam hal kompetensi paedagogis dasar bagi seorang guru, yang meliputi komptensi membuka dan menutup pelajaran, keterampilan bertanya, keterampilan menjelaskan, dan sebagainya. Terlebih dimaksimalkan dengan penguasaan metode terbaru, yaitu metode "Hypnoteaching" dalam pembelajaran bagi Para Guru MTs.

12 Wawancara, Jum'at 27 Mei 2016.

${ }^{13}$ Wawancara, Jum'at 27 Mei 2016. 
Strategi pembinaan yang digunakan dalam kegiatan ini terdiri atas dua cara: 1). Memberi penjelasan dan pemahaman kepada guru MTs Al-Ikhlasiyah 2). Latihan praktik/pendampingan. Pihak-pihak yang terlibat dalam kegiatan pembinaan madrasah ini antara lain adalah dosen-dosen Fakultas Ilmu Tarbiyah dan Keguruan (FITK) IAIN Mataram yang memiliki kualifikasi atau keahlian di bidang keterampilan dasar mengajar, termasuk yang sudah berkualifikasi selaku asesor. Keterlibatan dosen-dosen ini adalah dalam rangka memberikan pemahaman kepada guru-guru oleh narasumber tentang keterampilan dasar mengajar serta melakukan pembinaan secara bertahap. Selanjutnya yang terlibat dalam kegiatan ini (yang menjadi peserta) adalah seluruh guru MTs Al-Ikhlasiyah yang berjumlah 15 orang. Di luar narasumber dari Fakultas Ilmu Tarbiyah dan Keguruan IAIN Mataram, para guru MTs yang berkualifikasi S1 Kependidikan turut serta dilibatkan, terutama pada saat praktik secara simultan, sesuai dengan instrument keterampilan dalam pembelajaran yang ada.

Di dalam kegiatan pembinaan kompetensi paedagogis guru berbasis keterampilan dasar mengajar di MTs Al-Ikhlasiyah Perampuan, Kecamatan Labuapi, Kabupaten Lombok Barat, instrument yang digunakan sebagai standar praktik bagi guru-guru yang sedang dibina adalah instrumen penilaian kegiatan praktik mengajar (peer teaching) dalam kegiatan PLPG menggunakan Kurikulum 2013 dengan pendekatan saintifik.

\section{PEMBAHASAN}

\section{Upaya Peningkatan Kompetensi Pedagogis Guru}

Salah satu faktor penting yang akan mempengaruhi keberhasilan pembelajaran adalah kemampuan guru dalam mengelola pembelajaran dari awal sampai akhir pembelajaran. Paling tidak, seorang guru yang baik perlu memiliki keterampilan dasar dalam mengajar. Yaitu sebagai berikut:

1. Keterampilan Membuka Pelajaran

Kegiatan membuka pelajaran merupakan keterampilan dasar yang harus dan wajib dimiliki oleh guru, dengan keterampilan membuka proses pembelajaran maka seorang guru akan terarah dalam menyampaikan materi 
yang diajarkan kepada siswanya, ${ }^{14}$ jika pendidik atau guru mampu dan bisa membuka pelajaran dengan baik maka guru tersebut akan mampu mengarahkan siswa sesuai dengan arahan dari guru, akan tetapi jika guru tidak berhasil atau gagal membuka pelajaran dengan baik maka akan berpengaruh terhadap proses penyampaian materi pembelajaran. ${ }^{15}$

Kegiatan membuka pelajaran mempunyai banyak sekali tujuan, diantaranya:

a. Membangkitkan motivasi dan perhatian

b. Membuat siswa memahami batas tugasnya

c. Membantu siswa memahami hubungan berbagai materi yang disajikan

d. Membantu siswa mengetahui tingkat keberhasilannya

Membuka pelajaran adalah kegiatan yang dilakukan guru untuk menciptakan suasana yang dapat mempersiapkan mental, perhatian, dan gambaran tentang apa yang akan dipelajari dan dikuasai siswa sehingga tercipta kondisi awal pelajaran yang terarah dan dinamis, beberapa komponen membuka pelajaran diantaranya : Menarik perhatian siswa dengan berbagai cara, Menimbulkan motivasi dengan cara (1) menciptakan kehangatan dan keantusiasan (2) menimbulkan rasa ingin tahu (3) mengemukakan ide yang bertentangan (4) dan memperhatikan minat siswa, Memberikan acuan dengan cara (1) mengemukakan tujuan dan batas batas tugas (2) menyarankan langkah-langkah yang akan dilakukan (3) mengingatkan masalah pokok yang akan dibahas, dan (4) mengajukan pertanyaan, Membuat kaitan, dengan cara (1) mengajukan pertanyaan apersepsi, atau (2) merangkum pelajaran yang lalu.

2. Keterampilan Menjelaskan

Menjelaskan adalah kegiatan untuk menyampaikan informasi atau materi pelajaran dalam tata urutan yang terencana secara sistematis sehingga dengan mudah dapat dipahami oleh siswa. ${ }^{16}$ Kegiatan menjelaskan bertujuan untuk : Membimbing siswa memahami berbagai konsep, hukum, prinsip, atau prosedur, Membimbing siswa menjawab pertanyaan "mengapa" secara

\footnotetext{
${ }^{14}$ Azhar Arsyad. Media Pembelajaran. (Jakarta: PT Raja Grafindo Persada, 2008), h. 15.

${ }^{15}$ Abu Ahmadi dan Nur Uhbiyati, I/mu Pendidikan, (Jakarta: Rineka Cipta, 1991), h. 6

${ }^{16}$ Azhar Arsyad. Media Pembelajaran...47
} 
bernalar, Melibatkan siswa untuk berfikir, Mendapatkan balikan mengenai pemahaman siswa, Menolong siswa menghayati berbagai proses penalaran.

Keterampilan menjelaskan terdiri dari berbagai komponen sebagai berikut:

1. Komponen merencanakan penjelasan, yang mencakup:

a. Isi pesan (pokok-pokok materi)yang dipilih dan disusun secara sistematis disertai contoh-contoh

b. Hal-hal yang berkaitan dengan karakteristik penerima pesan (siswa)

2. Komponen menyajikan penjelasan, yang mencakup hal-hal berikut.

a. Kejelasan, yang dapat dicapai dengan berbagai cara, seperti bahasa yang jelas, berbicara lancar, mendefinisikan istilah-istilah teknis, dan berhenti sejenak untuk respons siswa atau penjelasan siswa.

b. Penggunaan contoh dan ilustrasi, yang dapat mengikuti pola induktif atau pola deduktif.

c. Pemberian tekanan pada bagian-bagian yang penting dengan cara: penekanan suaara, membuat ikhtisar, atau mengemukakan tujuan.

d. Balikan tentang penjelasan yang disaji dengan melihat mimik siswa atau mengajukan pertanyaan. ${ }^{17}$

Dalam menerapkan keterampilan menjelaskan, perlu di perhatikan halhal sebagai berikut:

a. Penjelasan dapat diberikan pada awal, tengah, ataupun pada akhir pelajaran sesuai dengan keperluan

b. Penjelasan harus relepan dengan tujuan

c. Materi yang dijelaskan haru bermakna

d. Penjelasan yang diberikan sesuai dengan kemampuan dan latar belakang siswa

3. Keterampilan Menutup

Kegiatan ini dimaksudkan untuk memberikan penegasan, rangkuman, atau kesimpulan, dan pemberian balikan atas respons siswa, keterampilan menutup pelajaran terdiri atas komponen berikut:

17 Tim FKIP, Pemantapan Kemampuan Mengajar (PKM)- PGSD (Jakarta : Universitas Terbuka, 2008), h. 18 
a. Meninjau kembali dengan cara merangkum atau membuat ringkasan

b. Mengadakan evaluasi penguasaan siswa, dengan meminta mereka (1) mendemonstrasikan keterampilan, (2) menerapkan ide baru padaa situasi lain, (3) mengekspresikan pendapat sendiri, dan (4) memberikan soal tertulis (5) memberikan tindak lanjut yang dapat berupa pekerjaan rumah, merancang sesuatu atau berkunjung ke suatu tempat.

Perlu diingat bahwa kegiatan membuka dan menutup pelajaran tidak hanya dilakukan pada awal dan akhir kegiatan, tetapi juga pada awal dan akhir setiap penggal kegiatan, dengan catatan bahwa ini harus bermakna dan berkesinambungan

\section{Penerapan Metode Hypnoteaching dalam Pembelajaran}

\section{Hypnoteaching}

Saat ini, banyak metode pembelajaran yang telah dikembangkan dan diterapkan di sekolah-sekolah. Salah satu metode yang saat ini mulai banyak dikembangkan adalah metode pembelajaran Hypnoteaching. Hypnoteaching merupakan metode pembelajaran yang dalam menyampaikan materi, guru memakai bahasa-bahasa bawah sadar yang bias menumbuhkan ketertarikan tersendiri kepada anak didik. Dari asal kata hypnoteaching merupakan perpaduan dua kata, yaitu hypnosis dan teaching. Hypnosis berarti mensugesti dan teaching yang berarti mengajar. Jadi, dapat diartikan bahwa hypnoteaching adalah usaha untuk menghipnosis atau mensugesti anak didik supaya menjadi lebih baik dan prestasinya meningkat.

Menurut Novian Triwidia Jaya ${ }^{18}$, hypnoteaching merupakan perpaduan pengajaran yang melibatkan pikiran sadar dan bawah sadar. Hypnoteacahing ini merupakan metode pembelajaran yang kreatif, unik, sekaligus imajinatif. Sebelum pelaksanaan pembelajaran, para anak didik sudah dikondisikan untuk belajar. Dengan demikian, anak didik mengikuti pembelajran dalam kondisi segar dan siap untuk menerima materi pelajaran. Untuk mempersiapkan halhal tersebut, tentu guru sendiri juga dituntut untuk stabil baik secara

${ }^{18}$ Novian Triwidia Jaya, Hypno Teaching "Bukan Sekedar Mengajar" (Bekasi: D-Brain, 2010), h. 41. 
psikologis, maupun secara psikis. Denga begitu, guru pun mempunyai kesiapan yang penuh dalam mengajar para ank didiknya.

Sementara menurut Muhammad Noer ${ }^{19}$, dalam hypnoteaching guru bertindak sebagai penghipnotis, sedangkan anak didik berperan sebagai suyet atau orang yang dihipnotis. Dalam pembelajaran, sebenarnya guru tidak perlu menidurkan anak didiknya ketika memberikan sugesti. Guru cukup menggunakan bahasa yang persuasif sebagai alat komunikasi yang sesuai dengan harapan anak didik. Hal yang harus diingat adalah guru harus berusaha menyampaiakn kepada anak didik dengan bahasa yang mudah dipahami oleh anak didik. Sebab, dengan bahasa yang mudah dipahami oleh anak didik. Sebab, sangat tidak mungkin hypnosis bisa berjalan secara efektif jika suyet tidak paham akan maksud dari penghipnotis.

Adapun unsur-unsur yang perlu diketahui dalam hypnoteaching adalah; ${ }^{20}$ Penampilan Guru, Rasa simpati, Sikap yang empatik, Penggunaan bahasa, Motivasi anak didik dengan cerita atau kisah, Peraga (bagi yang kinestetik), Jika ingin menguasai pikiran anak didik, kuasai terlebih dahulu hatinya.

\section{Manfaat Hypnoteaching}

Saat ini kita sering melihat banyak sekolah yang merasa kewalahan dan kesulitan dalam menghadapi berbagai permasalahan yang dialami oleh para anak didiknya. ${ }^{21}$ Mulai dari hal "kecil", seperti malas belajar, tidak bersemangat dalam mengikuti proses pembelajaran, mempunyai prestasi belajar yang rendah, sampai pada penyimpangan-penyimpangan perilaku yang "besar" yang dilakukan oleh anak didik. Bahkan, tidak sedikit dari penyimpangan itu termasuk dalam kenakalan dan tindakan kriminal.

Dari penjelasan sebelumnya, dapat diketahui bahwa metode hypnoteaching hanya bermain pada kekuatan pikiran alam bawah sadar. Melalui penguasaan hypnoteaching, para akan menjadi lebih memahami pola

${ }_{19}$ Muhammad Noer, Hypno Teaching for Succes Learning (Yogyakarta: Pustaka Insan Madani, 2010), h. 21.

${ }^{20}$ Ibid, h. 137.

${ }^{21}$ Muhammad Noer, Hypno Teaching for Succes Learning... 112 
kerja pikiran anak didik yang sebenarnya. Dengan kata lain, kita dapat memahami bahwa hypnoteaching adalah pengemabangan pada metode pembelajaran. Melalui hypnoteaching, guru dapat melakukan pendekatan konseptual yang baru terahadap anak didiknya. Selain itu, metode ini juga memberikan "terapi penyembuhan" pada anak didik yang mempunyai permasalahan belajar maupun psikis. ${ }^{22}$

Adapun beberapa manfaat yang bisa dicapai melalui penerapan metode hypnoteaching dalam pembelajaran di dalam kelas sebagai berikut :

a. Pembelajaran menjadi menyenangkan dan lebih mengasyikkan, baik bagi anak didik, maupun bagi guru.

b. Pembelajaran dapat menarik perhatian anak didik melalui berbagai kreasi permainan yang diterapkan oleh guru.

c. Guru menjadi lebih mampu dalam mengelola emosinya.

d. Pembelajaran dapat menumbuhkan hubungan yang harmonis antara guru dan anak didik.

e. Guru dapat mengatasi anak-anak yang mempunyai kesulitan belajar melalui pendekatan personal.

f. Guru dapat menumbuhkan semangat anak didik dalam belajar melalui permainan hypnoteaching.

g. Guru ikut membantu anak didik dalam menghilangkan kebiasaan-kebiasaan buruk yang mereka miliki. ${ }^{23}$

\section{Kondisi Komunitas MTs Al-Ikhlasiyah yang Diharapkan}

Berdasarkan hal tersebut, dipandang layak jika kompetensi guru MTs AlIkhlasiyah Perampuan terus ditingkatkan, sehingga mampu menjalankan tugas profesinya dengan baik dan berhasil maksimal. Ini terutama ditujukan kepada 15 orang guru yang menjadi sasaran pemberdayaan ini (sebagaimana tertera dalam tabel 1 di atas). Sedangkan murid yang sedang aktif belajar di MTs Al-Ikhlasiyah cukup banyak, sebagaimana tertera dalam tabel berikut:

\footnotetext{
${ }^{22}$ Novian Triwidia Jaya, Hypno Teaching "Bukan Sekedar Mengajar...44

${ }^{23}$ Djamarah dan Saiful Bahri, Guru dan Anak Didik dalam Interaksi Edukatif (Jakarta: PT Rineka Cipta, 2005), h. 65
} 
Transformasi, Vol. 12, No. 1, Januari 2016: 16-30

Tabel 2: Data seluruh siswa MTs Al-Ikhlashiyah Perampuan Kecamatan Labuapi Lombok Barat Tahun Pelajaran 2016/2017. ${ }^{24}$

\begin{tabular}{|c|c|c|c|c|c|c|c|c|}
\hline \multirow{2}{*}{$\begin{array}{l}\text { Tahun } \\
\text { Ajaran }\end{array}$} & \multicolumn{2}{|c|}{ Kelas 1} & \multicolumn{2}{|c|}{ Kelas 2} & \multicolumn{2}{|c|}{ Kelas 3} & \multicolumn{2}{|c|}{$\begin{array}{c}\text { Jumlah } \\
\text { ( kelas } 1+2+3\end{array}$} \\
\hline & $\begin{array}{c}\text { Jml } \\
\text { Siswa }\end{array}$ & $\begin{array}{c}\text { Jml } \\
\text { Rombel }\end{array}$ & $\begin{array}{c}\text { Jml } \\
\text { Sisw } \\
\text { a }\end{array}$ & $\begin{array}{c}\text { Jml } \\
\text { Rombel }\end{array}$ & $\begin{array}{c}\text { Jml } \\
\text { Sisw } \\
\text { a }\end{array}$ & $\begin{array}{c}\text { Jml } \\
\text { Rombel }\end{array}$ & $\begin{array}{c}\text { Jml } \\
\text { Sisw } \\
\text { a }\end{array}$ & $\begin{array}{c}\text { Jml } \\
\text { Rombel }\end{array}$ \\
\hline $2011 / 2012$ & 36 & 1 & 13 & 1 & 27 & 1 & 76 & 3 \\
\hline $2012 / 2013$ & 32 & 1 & 39 & 1 & 34 & 1 & 105 & 3 \\
\hline $2013 / 2014$ & 63 & 2 & 26 & 1 & 27 & 1 & 116 & 4 \\
\hline $2014 / 2015$ & 85 & 3 & 60 & 2 & 26 & 1 & 171 & 6 \\
\hline $2015 / 2016$ & 55 & 2 & 72 & 3 & 44 & 2 & 171 & 7 \\
\hline $2016 / 2017$ & 70 & 3 & 50 & 2 & 63 & 3 & 183 & 8 \\
\hline
\end{tabular}

Atas dasar itu, upaya peningkatan kompetensi guru tidak dapat ditawartawar lagi. Hal ini misalnya dapat dilakukan melalui penguasaan berbagai keterampilan dasar mengajar yang harus dikuasai guru. Berbagai keterampilan dasar mengajar dimaksudkan meliputi keterampilan membuka dan menutup pelajaran, keterampilan menjelaskan, keterampilan bertanya, keterampilan mengadakan variasi, keterampilan memberi penguatan, keterampilan mengajar kelompok kecil dan perorangan, keterampilan mengelola kelas, dan keterampilan membimbing diskusi kelompok kecil.

Tujuan pembinaan ini adalah memberikan pemahaman dan kesadaran kepada guru MTs Al-Ikhlasiyah Perampuan (terutama yang tidak berlatar belakang sarjana kependidikan dan atau yang masih D1 dan SMA) tentang pentingnya memiliki kemampuan aplikatif berbagai keterampilan dasar mengajar dalam pelaksanaan pembelajaran. Kemudian meningkatkan kompetensi guru MTs AlIkhlasiyah Perampuan, sehingga dapat melaksanakan kegiatan pembelajaran secara baik. Selanjutnya meningkatkan kemampunan penyusunan RPP yang baik dan bertanggung jawab.

\section{Strategi Pembinaan Upaya Peningkatan Kompetensi Paedagogis Guru Berbasis Keterampilan Dasar Mengajar}

Dalam kegiatan pembekalan-pelatihan ini dimaksudkan untuk memberikan orientasi dengan tujuan memberikan wawasan dan pengetahuan bagi segenap

${ }^{24}$ Dokumentasi, MTs Al-Ikhlashiyah Perampuan, 27 Mei 2016. 
guru MTs Al-Ikhlasiyah yang menjadi peserta sebanyak 15 orang tentang konsepkonsep upaya peningkatan kompetensi paedagogis guru berbasis keterampilan dasar mengajar yang mutakhir. Kegiatan ini dalam penerapannya menggunakan metode ceramah, diskusi maupun latihan tugas tentang berbagai penting terkait kompetensi paedagogis guru. Termasuk dalam hal ini adalah konsep hypnoteaching dalam pembelajaran sebagai bagian dari metode menjelaskan. Sedangkan pendampingan merupakan kegiatan sebagai follow up dari kegiatan pembekalan-pelatihan. Di mana peserta akan didampingi untuk menata dan menghasilkan berbagai skill terbaru yang terkait dengan kepentingan implementasi kompetensi paedagogis guru berbasis keterampilan dasar mengajar, serta aplikasi hypnoteaching dalam pembelajaran.

\section{Hasil yang Dicapai dan Rencana Tindak Lanjut}

1. Keberhasilan

Secara umum kegiatan ini berjalan sukses. Hal ini bisa dilihat pertama, fasilitator hadir semua sesuai dengan jadwal. Mereka juga menyampaikan materi yang dilengkapi dengan makalah atau bahan bacaan yang relevan sehingga memudahkan peserta untuk menerima dan memahami materi. Kedua, para peserta hadir semua, sesuai dengan quota yang ditetapkan, yaitu keluarga besar Madrasah Tsanawiyah Al-Ikhlasiyah, Desa Perampuan, Kecamatan Labuapi, Kabupaten Lombok Barat sejumlah 15 orang guru dengan rincian 5 orang guru berlatar pendidikan S1 non kependidikan dan 10 orang belum berkualifikasi S1. Sehingga peserta berasal dari semua unsur yang diharapkan dapat menyukseskan program pembinaan kompetensi paedagogis guru berbasis keterampilan dasar mengajar ini. Semua pesertadengan antusias mengikuti kegiatan dari awal sampai akhir. Fasilitas yang disediakan panitia dan pihak Madrasah Tsanawiyah Al-Ikhlasiyah, Desa Perampuan, Kecamatan Labuapi, Kabupaten Lombok Barat cukup memadai sehingga turut memperlancar kegiatan ini. 
Transformasi, Vol. 12, No. 1, Januari 2016: 16-30

2. Hambatan-Hambatan

Secara prinsip tidak ada hambatan yang berarti. Namun demikian ada beberapa catatan untuk diperhatikan.

a. Dari segi dana: Kegiatan ini hendaknya didukung dengan dana yang lebih cukup memadai, sehingga panitia dapat konsentrasi secara penuh pada pelaksanaan kegiatan. Terlebih, kegiatan ini akan lebih maksimal berjalan jika setelah pelatihan dan pendampingan, diselingi dengan karyawisata ke sekolah/ madrasah yang lebih maju yang telah lama berhasil menerapkan kompetensi paedagogis guru berbasis keterampilan dasar mengajar serta implementasi hypnoteaching dalam pembelajaran seperti SMAN 01 Mataram, MAN 1 Mataram, dan MAN 2 Mataram.

b. Dari segi peserta: perlu mempersiapkan secara maksimal field note atau jurnal sebagai persyaratan yang telah ditetapkan panitia, sehingga membantu panitia dalam dokumentasi bukti fisik kegiatan.

c. Dari segi instansi terkait: perlu mendukung kegiatan positif semacam ini dengan dukungan moril dan materilnya.

3. Rencana Tindak Lanjut

Rencananya kegiatan pembinaan yang mencakup pembekalan-pelatihan dan pendampingan ini akan diadakan secara berkala tiap tahun dengan peserta tidak saja berasal dari kalangan guru di lingkungan Madrasah Tsanawiyah Al-Ikhlasiyah, Desa Perampuan, Kecamatan Labuapi, Kabupaten Lombok Barat, namun diperluas ke sekolah/madrasah-madrasah lain yang menghajatkannya di wilayah Provinsi Nusa Tenggara Barat, selama Pimpinan IAIN Mataram, khususnya melalui LP2M, tetap memberikan support-nya, baik moril maupun materiil.

\section{PENUTUP}

Demikian pelaksanaan kegiatan pemberdayaan atau Pembinaan Kompetensi pedagogis Guru Berbasis Keterampilan Dasar Mengajar dan Metode Hypnoteaching di Madrasah Tsanawiyah Al-Ikhlasiyah Desa Perampuan, Kecamatan Labuapi, Kabupaten Lombok Barat Tahun 2016. Harapannya berbagai 
data dan dokumentasi serta kegiatan secara verbal bisa dipertanggungjawabkan. Kesimpulannya; Kegiatan pemberdayaan Kompetensi Paedagogis Guru Berbasis Keterampilan Dasar Mengajar dan Metode Hypnoteaching di Madrasah Tsanawiyah Al-Ikhlasiyah Desa Perampuan, Kabupaten Lombok Barat ini telah berjalan dengan lancar, lengkap dengan kelebihan dan kekurangannya.

Perlu menjadi catatan agar laporan ini bisa menjadi pegangan untuk dibaca, dikritisi serta diikuti yang baik dan dieliminir yang kurang baik. Harapan juga, semoga pelatihan dan kegiatan pembinaan yang telah selesai ini mampu membekali para peserta dengan berbagai pengetahuan dan pengalaman dalam soal peningkatan kualitas penguasaan secara teori dan praktik terkait kompetensi paedagogis guru berbasis keterampilan dasar mengajar serta metode hypnoteaching, sehingga dapat mendorong mereka untuk menjadi tenaga pengajar yang profesional dan handal.

\section{DAFTAR PUSTAKA}

Ahmadi, Abu dkk., IImu Pendidikan, Jakarta: Rineka Cipta, 1991.

Arsyad, Azhar, Media Pembelajaran, Jakarta: PT Raja Grafindo Persada, 2008.

Dimyati dan Mudjiono, Belajar dan Pembelajaran, Jakarta: Rineka Cipta, 1999.

Djamarah, Saiful Bahri, Guru dan Anak Didik dalam Interaksi Edukatif, Jakarta: PT Rineka Cipta, 2005.

Hanafiah, dkk., Konsep Strategi Pembelajaran, Bandung :PT Refika Aditama, 2010.

Jaya, Novian Triwidia, Hypno Teaching "Bukan Sekedar Mengajar, Bekasi: D-Brain, 2010.

Mulyasa, E., Menjadi Guru Profesional, Bandung: Remaja Rosdakarya, 2005.

Munadi, Yudhi, Media Pembelajaran (Sebuah Pendekatan Baru), Jakarta: Gaung Persada (GP), 2012. 
Transformasi, Vol. 12, No. 1, Januari 2016: 16-30

Noer, Muhammad, Hypno Teaching for Succes Learning, Yogyakarta: Pustaka Insan Madani, 2010.

Nurrahmah, Potret Buram Pendidikan Daerah Miskin di Indonesia: Becermin dari Dompu Nusa Tenggara Barat, Mataram: Insan Madani Institute Mataram, 2014.

Saudagar, Fachruddin dan Ali Idrus, Pengembangan Profesionalitas Guru, Jakarta: Gaung Persada, GP Press, 2009.

Shaleh, Abdul Rahman, Pendidikan Agama \& Pembangunan Watak Bangsa, Jakarta: PT Raja Grafindo Persada, 2005.

Situmorang, Robinson, Strategi Pembelajaran Berbasis Multiple Intelligence (MI) untuk Pencapaian Kompetensi dalam Pembelajaran, dalam Mozaik Teknologi Pendidikan, eds. Dewi Salma Prawiradilaga dan Eveline Siregar, Jakarta: Kencana, 2008.

Soetjipto dan Kosasi, Profesi Keguruan, Jogjakarta: CV Wicaksana, 2012.

Suyanto dan M.S. Abbas, Wajah dan Dinamika Pendidikan Anak Bangsa, Yogyakarta: Adicita Karya Nusa, 2004.

Tilaar, H.A.R, Perubahan Sosial dan Pendidikan: Pengantar Pedagogik Transformatif untuk Indonesia, Jakarta: PT Grasindo, 2002.

Tim FKIP, Pemantapan Kemampuan Mengajar (PKM)- PGSD, Jakarta: Universitas Terbuka, 2008.

Yustisia, N., HYPNOTEACHING: Seni Mengeksplorasi Otak Peserta Didik Jogjakarta: Ar-Ruzz Media, 2012. 